Article

\title{
The Preservation of Productive Activities in Brussels: The Interplay between Zoning and Industrial Gentrification
}

\author{
Sarah De Boeck* and Michael Ryckewaert \\ Department of Geography, Vrije Universiteit Brussel, 1050 Brussels, Belgium; E-Mails: sarah.de.boeck@vub.be (S.D.B.), \\ michael.ryckewaert@vub.be (M.R.) \\ * Corresponding author
}

Submitted: 31 March 2020 | Accepted: 18 September 2020 | Published: 29 September 2020

\begin{abstract}
Urban activities such as housing, productive space, green space, offices, etc., compete for scarce urban land, especially in cities with population growth, such as London and Brussels. Thereby, low-value uses such as production have a more vulnerable position in a private property market governed by real estate dynamics in comparison to high-value uses such as offices and housing. While local authorities of post-industrial cities grow more susceptible to revitalizing their relationship with productive activities, they risk losing the space to do so due to industrial gentrification. Based on the disappearance of production space in the case of the Brussels Capital Region (BCR), this article aims at evaluating how the BCR supports urban production, with a clear focus on zoning and the provision of production space. Although the BCR is a post-industrial city, it continues to lose production space at a rapid pace. Employing an analytical framework of urban settlement patterns of production, we analyse the production-related zone typologies in inner-city areas as well as in more peripheral monofunctional and mixed areas of the BCR. Our analysis of the production-related zone typologies of the BCR land-use plan demonstrates that industrial gentrification plays an important role in current deindustrialization processes. This article presents zoning strategies to regulate the private property market as well as public land strategies to preserve urban production space.
\end{abstract}

\section{Keywords}

industrial gentrification; industrial retention; mixed-use development; urban development; urban production; zoning

Issue

This article is part of the issue "Planning for Local Economic Development: Research into Policymaking and Practice" edited by Godwin Arku (University of Western Ontario, Canada) and Evan Cleave (Ryerson University, Canada).

(C) 2020 by the authors; licensee Cogitatio (Lisbon, Portugal). This article is licensed under a Creative Commons Attribution 4.0 International License (CC BY).

\section{Introduction}

In the Brussels Capital Region (BCR) as well as in other European post-industrial cities, there is a contradiction between renewed policy attention for urban production since the financial crisis of 2008 and the empirical observation of ongoing deindustrialization. The recent urban industrial policy plans, written after the 2008 crisis, describe a range of urban production strategies aimed at maintaining and growing production. Although almost none of these plans include direct guidelines or strategies concerning the provision of spaces in which these activities take place, several policy measures-such as land- use plans and zoning-have a spatial impact on urban production. The aim of this article is therefore threefold. First, it problematizes the provision of urban production space by empirically demonstrating the rapid disappearance of large amounts of production space in the case of the BCR. Second, the article identifies the actors and mechanisms responsible for the disappearance of production space in the various zoning categories of the BCR land-use plan. And third, it formulates recommendations to safeguard urban production space.

In doing so, this article does not question the legitimacy of the BCR's policy goals of supporting urban production but accepts it as a given, nor does it question 
the hypothesis that "a good city has industry" (Brearly, 2016). We refer to various authors who provide empirical evidence and arguments for the need for urban production, thereby using a variety of social, ecological, and economic arguments, together with data about sustainability, labour markets, urban ecosystems, circular economy, mobility, etc. To name a few: Cities of Making (2018), Fitzgerald and Leigh (2002), Hill (2020), Kampelmann (2017), Lane (1995), and Lester, Kaza, and Kirk (2013). Instead, this article aims at evaluating how the BCR supports urban production, with a clear focus on zoning and the provision of production space. Next to zoning strategies, mobility, logistics, and infrastructure policies also played an important role in deindustrialization and the suburbanization of production space (Ryckewaert, 2011). In this article, we focus on the use of zoning as a planning instrument in curbing deindustrialization. The logistics dimension exceeds the scope of this article, even if it is a crucial one and has clear links with zoning.

This article proceeds as follows: Section 2 describes the theoretical approach. Following the analysis of the micro-data, we hypothesize that industrial gentrification is a significant factor of deindustrialization in the BCR. We introduce the hypothesis via recent research about industrial gentrification (Curran, 2007, 2010; Ferm \& Jones, 2016, 2017; Wolf-Powers, 2005), whereby highvalue uses (e.g., offices, housing) displace low-value uses (e.g., recreation, production).

Section 3 deals with the methodological approach. The section starts with sketching the research context of the case of the BCR. This article uses an analytical framework of urban settlement patterns of production (USPPs) to demonstrate how production continues to leave the city. This framework allows us to describe the disappearance of production space by using a structured narrative that recurs in every section of this article and to link the disappearance of production space to land-use plans and urban morphologies. The main research question of this article, then, is whether the zoning strategies of the BCR land-use plan contain protective measures to preserve urban production land. Next to the use of macro-data on the disappearance of production space on the regional scale, we also use a set of micro-data on building permits (BPs) of the municipality of Sint-Jans-Molenbeek, the former industrial heartland of the BCR. This micro-data on BPs allows us to understand who the actors involved in industrial conversion are. Private persons are responsible for more than $50 \%$ of the transformations of former production spaces into housing.

In Section 4, we analyse the disappearance of production space in the case of the BCR in each of the zoning typologies related to the production of the BCR land-use plan (BCR, 2017). We illustrate how industrial gentrification is responsible for the loss of productive space in the BCR in all of the zoning typologies. While private actors drive conversions from production space into housing in inner-city areas, public authorities in particular are driving the transformation of mono-industrial zones.
Just like in London (Ferm \& Jones, 2017), in the BCR this mainly happens through changing land-use plans. If the current zone typologies do not protect production space, can other zone typologies preserve production space in inner-city areas? Or, can we improve the existing zoning measures?

Section 5 displays three 'passive' zoning strategies to regulate the private property market: (1) improving the zoning instrument enterprise area of urban development (EAUD); (2) heritage regulation; and (3) microzoning. This final section additionally presents two more 'active' public strategies to maintain production space: (1) expanding public production assets; and (2) the Community Land Trust (CLT) model, where long-term stewardship of affordable land replaces the barriers between ownership and leasing.

\section{Theoretical Approach}

\subsection{Identifying Urban Production}

Academics and policymakers use various definitions to delineate urban production. Recurring words in no particular order are manufacturing, industry, production, maintenance, and repair. Sometimes, construction is added (De Boeck, Bassens, \& Ryckewaert, 2019) as well as activities related to the circular economy such as urban mining and recycling (Cities of Making, 2018; Hill, 2020). Conflicting opinions arise on whether to include immaterial activities in the definition of urban production, such as ICT, academic and technological activities, graphic design, etc. We adopt a broad definition that includes immaterial production because this allows us to study a diverse range of productive activities in terms of their spatial needs and their emergence in the USPPS.

\subsection{Deindustrialization and Industrial Gentrification in Relation to Zoning Policy}

Deindustrialization is usually explained by a combination of internal (Rowthorn \& Ramaswamy, 1999; Tregenna, 2011) and external factors (Ryckewaert, 2011; Saeger, 1997), such as technological innovation and outsourcing to low-wage countries. This article focuses on a more recent account of deindustrialization: industrial gentrification, or the pushing out of production space through real estate dynamics, often underpinned by changing landuse policy. Two different bodies of literature reveal a clear link between planning instruments, real estate dynamics, and industrial gentrification: critical urban geography and urban planning. To name but a few studies: Camerin (2019) and Charnock, Purcell, and Ribera-Fumaz (2014) on the Poblenou district in Barcelona; Curran (2007, 2010) and Wolf-Powers (2005) on Williamsburg in New York; Ferm and Jones $(2016,2017)$ on London; and Savini and Aalbers (2016) on Milan. Both bodies of literature describe cities and regions that are predominantly governed by a private land market. Without explic- 
itly naming Smith (1987), the authors mentioned above demonstrate that when there is a difference between the current rent of a property and its potential future rent, there is a strong tendency to increase the rent and value. They also demonstrate that this dynamic does not only apply to residential development, as Smith (1987) describes, where higher-value homes replace lower-value homes, but also to lower-value-and thus more economically vulnerable-uses such as parks, social services, and, in the case of this article, production space.

Based on an analysis of urban plans and research-bydesign for urban production, urban planning literature comes to conclusions similar to those of critical urban geography readings about project development in cities such as Milan (Savini \& Aalbers, 2016) and the transformation of the formerly industrial district of Poblenou into the 22@ area in Barcelona (Camerin, 2019). They frame the conclusions differently, however. The field of urban planning frames the relation between planning instruments, real estate dynamics, and industrial gentrification as an extra explanation of deindustrialization, and arguments are made in favour of reindustrializing the city (cf. Nawratek, 2017). The field of critical urban geography exposes this relation as a manifestation of violent capitalism aimed at developing entrepreneurial policy strategies and attracting foreign investors in a global intercity competition, without governmental concern for the former inhabitants and workers of these districts.

Concerning industrial gentrification and the preservation of affordable production land, most authors of industrial retention literature agree that mono-industrial zoning is the best strategy to guarantee the affordability of production land and reduce conflicts between production and housing (Borret, 2018; Fitzgerald \& Leigh, 2002). However, where multiple cases show how speculation initiates abandonment (Camerin, 2019), Armstrong and Lund (2005) and Schleicher and Hills (2010) point to the risk of underuse and abandonment because of a lack of investment incentives. They state that owners do not have any incentive to redevelop or invest in these areas, as the low land prices for such uses yield only a moderate return on investment as compared to residential redevelopment. If owners do not need the infrastructure in mono-industrial areas, there is no pressure to do something with it. According to the authors, this observation causes resistance of policy makers and citizens in cities with a growing population and a historical structural housing crisis, such as New York and London. Section 4 on the analysis of production space in the $B C R$ demonstrates that citizens do not oppose monoindustrial zones.

\section{Methodological Approach}

\subsection{Research Context of the Case of the BCR}

The BCR offers an excellent case to address the preservation of urban production space from a policy per- spective. Although the BCR is a post-industrial city, it continues to deindustrialize and lose production land. The term 'post-industrial' refers to the transition of a producing economy into a service economy caused by deindustrialization or a continuous decline in the share of manufacturing employment (Saeger, 1997). The BCR, for example, lost more than $85 \%$ of its manufacturing jobs between 1970 and 2014 (Vandermotten, 2014). Furthermore, the BCR is experiencing an increased competition between urban functions such as housing, production, green space, offices, etc. Since the region's development is predominantly driven by a private land market, high-value uses (housing, offices) generally win in this competition from low-value uses (production, green space) because they can afford to pay a higher rent.

The former industrial areas along the canal connect Brussels to the port of Antwerp and the North Sea in the north and Charleroi in the south. They are situated in the former valley of the Senne river. In cities such as Paris, a socio-spatial divide occurs between a wealthier city centre and more deprived peripheral areas such as the banlieues. But in the BCR, poorer residents (by average annual income) live in the city centre and the more affluent population lives in the periphery. The canal zone hosts the most substantial part of the demographic growth of the BCR. The latest projections predict a population increase of $5.6 \%$, or 68,063 people, between 2020 and 2040 (Brussels Instituut voor Statistiek en Analyse, 2020). This corresponds to an increase of approximately 840 extra households a year and illustrates the increasing pressure on land. In Figure 2, on the population growth of five inner-city neighbourhoods along the canal, we see the growth curve flattening, thereby indicating a slower growth than the previous decade.

\subsection{Empirical Data}

This article uses a mixed method of combining quantitative and qualitative data. To illustrate the disappearance of production space, we use macro-data on the evolution of land uses and their surfaces in the BCR between 2000 and 2018 from the Belgian Federal Land Registry Department (Statbel, 2018). To illustrate where and how production space disappears, we use a new local dataset of 447 BPs on 378 unique addresses in five out of 12 neighbourhoods of the Brussels municipality SintJans-Molenbeek between 1995 and 2019. The BPs are related to the conversion of productive space in former industrial inner-city neighbourhoods (for a more specific account of the methodology, see De Boeck, 2020). These BPs give us more insights into the actors of conversion and the types of new uses. To analyse the BCR zoning measures and the provision of urban production land, we combine an analysis of policy documents with comparative research through a literature review of zoning approaches in the cities of London, Barcelona, and Vienna. These cities use new zoning strategies to preserve urban production land that are similar to those used by the 
$B C R$. We focus on the conversion of mono-industrial into mixed-use zoning in combination with a set of strict planning rules that impose a vertical mix, with production on the ground floor and housing on the higher floors.

\subsection{Analytical Framework of USPPS}

To describe how and where production space disappears, we designed an analytical framework to categorize USPPs. This framework enables us to link the disappearance of production space in the BCR to academic literature about zoning, the BCR land-use plan, and the specific morphologies of production in the BCR.

The typology of our analytical framework consists of four distinct USPPs, as shown in Table 1. This section describes how our typology of USPPs is structured and clarifies the similarities to zoning categories for production as described in the academic literature, the corresponding zones in the BCR land-use plan, and the different morphologies, which together form the analytical framework.

\subsubsection{Planning Production Spaces through Zoning in Academic Literature}

The academic literature describes four main different types of zoning used to plan urban production: (1) monofunctional zoning; (2) horizontal mix with other economic activities or, (3), with housing; and (4) vertical mix with housing. We categorize these different types of zoning according to our typology of USPPs in Table 1. First, mono-industrial zoning corresponds to USPP-3 (Catungal, Leslie, \& Hii, 2009; Chapple et al., 2017; Charnock et al., 2014; Ferm \& Jones, 2016, 2017; Indegaard, 2009; Lester et al., 2013). Second, horizontal mixed-use zoning of production combined with other economic activities corresponds to USPP-2 (Cotter, 2012; Lane, 1995). Third, horizontal mixed-use zoning where production is combined with housing corresponds to USPP-1 and USPP-2 (Armstrong \& Lund, 2005; Lane, 1995; Schleicher \& Hills, 2010). And, fourth, Cotter (2012) and Leigh and Hoelzel (2012) propose a combination of densification and vertical mixed-use zoning with housing on top of production as a strategy to preserve and even expand urban industrial land, which corresponds to USPP-4.

\subsubsection{Planning Production Spaces through Zoning in the BCR Land-Use Plan}

The four zoning strategies for planning production in cities mentioned above also appear in the BCR land-use plan (BCR, 2017). This plan maintains a unique zoning methodology at the scale of the building block. Contrary to cities such as Barcelona or Vienna, who work with large zoning areas, every single building block in the BCR has its own set of uses and building prescriptions. The plan consolidated the existing land-use situation of 2001. The assigned use of a building block thus rather repre- sents the dominant-use situation as it was 20 years ago, based on an intensive site survey. The land-use plan, therefore, reflects the historical mix of production and living of the BCR's inner-city areas, indicating that the mixed and strongly mixed residential zoning typologies still hosted many production facilities in 2001.

The floor areas that are allowed for production spaces in every zone determine the different zoning categories. USPP-1 hosts residential and mixed residential zones, where $250 \mathrm{~m}^{2}$ of production space per building is allowed in residential areas and $1,000 \mathrm{~m}^{2}$ in the mixed zones. When a request is well-motivated and has undergone a public inquiry procedure, production space can be expanded to $500 \mathrm{~m}^{2}$ in the residential areas and $1,500 \mathrm{~m}^{2}$ in the mixed zones. USPP-2 is home to strongly mixed residential zones, with production spaces of up to $1,500 \mathrm{~m}^{2}$ per building. USPP-3 contains only monoindustrial zones: the areas for urban production and the areas for port activities and transport, where logistics and wholesale activities are also allowed, as well as small service spaces (cafés, restaurants, etc.) up to $300 \mathrm{~m}^{2}$ per building. USPP-4 hosts the EAUDs, with production spaces up to $2,000 \mathrm{~m}^{2}$ per building. When they are well-motivated and have undergone a public inquiry procedure, building projects of a minimum surface of $10,000 \mathrm{~m}^{2}$ are allowed. Here, $90 \%$ of the ground floor needs to be dedicated to production or wholesale, and a minimum of $40 \%$ of the total surface needs to be dedicated to housing.

\subsubsection{Morphologies of Urban Production Spaces}

The production-related zones correspond to four morphologies, with each a different granularity, scale, and type of production and housing mix (horizontal or vertical, interwoven, juxtaposed, or stacked). We based this method of categorizing on Hoppenbrouwer and Louw's (2005) multidimensional model of mixed-use developments. This model describes a range of typological and morphological dimensions of mixing functions (residential, office, shops) and allows us to approach urban production from a spatial and morphological perspective (for a more specific account of the methodology, see De Boeck, 2020; Hoppenbrouwer \& Louw, 2005).

To demonstrate the urban morphology of zones where production is allowed, we illustrate each USPP with a satellite image of a Brussels neighbourhood. To illustrate the interweaving of production and housing, we clarified the satellite images of the neighbourhoods in the colours blue and red. Blue stands for economic activities, red for housing (Moritz et al., 2013, p. 32).

USPP-1 represents fine-grained urban tissue with small-scale workspaces and warehouses, often built in the early 20th century, and an interwoven mix of functions in or between buildings. An example is a building block with production space in the courtyard surrounded by a closed front of housing (red surrounds blue in Table 1). USPP-2 represents mixed-grain tissue with 


\section{COGITATIO}

Table 1. Typology of USPP.

\begin{tabular}{lllllll}
\hline & & USPP-1 & & USPP-2 & USPP-3 & USPP-4 \\
\hline Mono-functional or & Mix & & Mix & & Mono & Mix
\end{tabular}

mixed-use zoning

BCR land-use plan regulations for zones where production is allowed + allowed $\mathrm{m}^{2}$ of production space per building

Residential areas $\left(250 m^{2}-500 m^{2}\right)$

Mixed residential

areas

$\left(1,000 \mathrm{~m}^{2}-1,500 \mathrm{~m}^{2}\right)$
Strongly mixed residential areas $\left(1,500 \mathrm{~m}^{2}\right)$
Areas for urban production

Areas for port activities and transport
Enterprise areas for urban development $\left(2,000 \mathrm{~m}^{2}\right.$; or projects of at least $10,000 \mathrm{~m}^{2}$, of which $90 \%$ production on the ground floor and $\min$. 40\% housing)
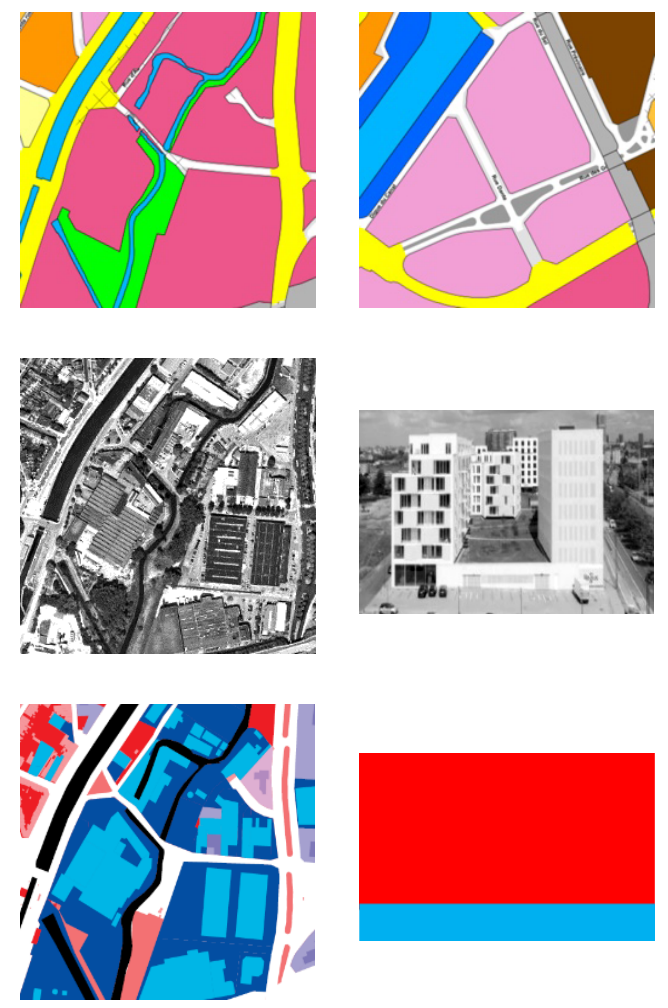

District

Coarse-grained grained

Horizontal

Horizontal

Vertical

Juxtaposed

Stacked

areas of residence

mixed areas of residence

strongly mixed areas of residence

areas for urban production

enterprise areas for urban development

areas for port activities and transportation areas

BCR land-use plan production zones.

Source: BCR (2017). 
the juxtaposition of production activities and housing at the scale of the building block. An example is a building block with mainly production spaces next to a building block of principally housing (a red building block juxtaposes a blue building block in Table 1). Both USPPs occur in the inner-city and former industrial area of Brussels. Table 1 illustrates this with two images from Sint-JansMolenbeek. USPP-3 or the horizontal mix at the district level in coarse-grained urban tissue appears as the juxtaposition of mono-functional areas, which is the case in the industrial zones in the north and south of the BCR. A vertical mix appears in USPP-4 at the scale of the building, the building block, and the district in coarse-grained tissue where functions are stacked upon one another (production on the ground floor in blue and housing on top in red in Table 1).

\section{Analysis: Production Space in the Case of the BCR}

\subsection{The Disappearance of Urban Production Space in the $B C R$}

Although Brussels was already established as a postindustrial city previously, empirical data from the BCR show a continuous and rapid decline of productive space since the year 2000. Table 2 shows how the BCR lost 106ha of productive buildings between 2000 and 2018 . That is a loss of $16 \%$ of its industrial assets.

In $2000,6 \%$ of the total surface of the BCR was allocated to industrial use. In 2018, that diminished to $4.2 \%$. In comparison, in its new Productive City plan, Vienna aims at allocating $5 \%$ of the total surface to production space (Stadt Wien, 2015).

\subsection{Where and How Does Production Space Disappear in the $B C R$ ?}

\subsubsection{Former Mixed Industrial Inner-City Areas}

Most losses of production space occur in the former industrial BCR municipalities along the canal: Anderlecht (-34ha), Sint-Jans-Molenbeek (-16ha), and Schaerbeek (-12ha); also, in Uccle $(-14 \mathrm{ha})$, which is further away from the canal but touches the southern industrial areas of Flanders. These surface data comprise production units of $1,000 \mathrm{~m}^{2}$ or more (De Voghel, Strale, Boswell, \& Coekelberghs, 2018). Since the regional government takes only surfaces of $1,000 \mathrm{~m}^{2}$ or more into account (De Boeck, Degraeve, \& Vandyck, in press), we use a micro-dataset of BPs in five neighbourhoods of the municipality of Sint-Jans-Molenbeek where bigger and smaller surfaces are considered, and zoom in on a former industrial part of the BCR.

We see in Figure 1 that the increasing amount of BPs partly coincides with the population increase in the same five neighbourhoods in Figure 2. The perimeter of the local dataset consists of building blocks in three zoning typologies of the BCR land-use plan: residential zones; mixed residential zones; and strongly mixed residential zones (BCR, 2017).

This local dataset of BPs in Sint-Jans-Molenbeek represents the conversions of production space in USPP-1 and USPP-2, as shown in Table 1, and allows us also to gain insight into the actors of conversion of former industrial inner-city areas, the new uses after the conversion, the sectors, and the mix of functions of the converted building projects.

Private persons are responsible for $50 \%$ of the conversions of production space. $70 \%$ of the once-industrial buildings owned by private individuals were transformed into housing. This percentage is much higher than the regional average of $47 \%$ of conversion into housing (De Voghel et al., 2018, p. 64). Most of these conversions are back houses, warehouses, and workshops situated in the courtyard of building blocks, similar to USPP-1 in Table 1. Businesses, representing a diverse set of economic activities, are responsible for $39 \%$ of all Molenbeek industrial conversions. A couple of sectors stand out, such as real estate $(29 \%)$, retail $(24 \%)$, construction (7.5\%), and wholesale (7.5\%), especially of construction materials. When looking at the types of BPs, half of the conversions done by real estate developers consist of merging two or more parcels to create residential apartment developments. $7 \%$ of the actors are

Table 2. Changes in the share of land uses of the BCR between 2000 and 2018.

\begin{tabular}{lrrr}
\hline BCR & 2000 & 2018 & \% of change between 2000 and 2018 \\
\hline Total built surface (ha) & 7,143 & 7,670 & $7 \%$ \\
Housing & 4,306 & 4,923 & $13 \%$ \\
Production and storage & 791 & 685 & $-16 \%$ \\
Offices & 281 & 274 & $-3 \%$ \\
Commerce & 518 & 492 & $-5 \%$ \\
Public buildings and other & 1,252 & 1,304 & $4 \%$ \\
Total unbuilt surface & 5,692 & 5,180 & $-10 \%$ \\
Not cadastral surface & 3,288 & 3,364 & $2 \%$ \\
Total surface & 16,123 & 16,214 & $1 \%$ \\
\hline
\end{tabular}

Source: Statbel (2018), processed by Sarah De Boeck. 


\section{COGITATIO}

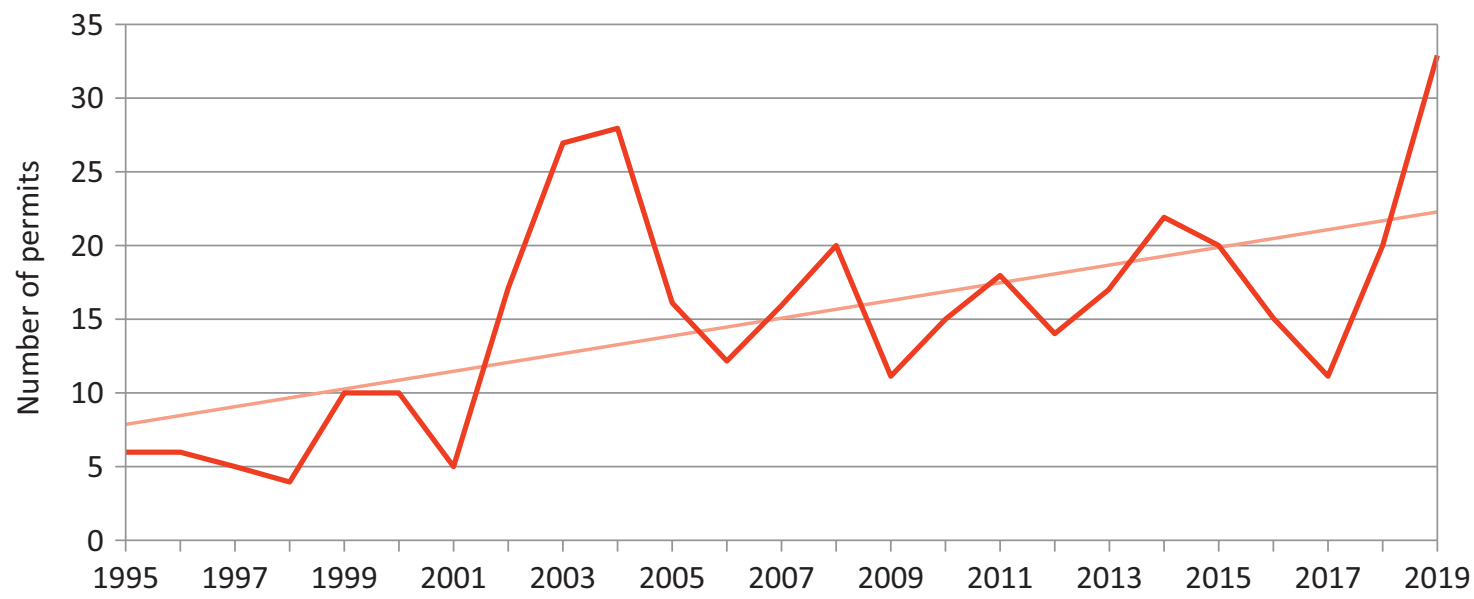

Figure 1. Number of permits for industrial conversions in Sint-Jans-Molenbeek between 1995 and 2019. Source: Courtesy of the Urbanistic Department of Sint-Jans-Molenbeek, processed by Sarah De Boeck.

non-profit organizations, of which half turn their industrial property into places of worship, principally mosques and evangelical churches. Fewer than $4 \%$ of these conversions are done by public bodies, mainly to construct social housing and buildings for social, cultural, and educational services.

Half of the reconversions are single-use projects, and the other half are mixed-use projects. The mixed-use projects of the Molenbeek dataset consist mostly of the conversion of production spaces into housing in combination with retail and parking. The main architectural typology is a shop on the ground floor and apartments on upper floors. Sometimes offices are added. In only two cases is the industrial back house demolished to make space for a garden. Only $10 \%$ of the BPs of single-use projects involve the renovation of manufacturing spaces. The other $90 \%$ concern: $37 \%$ housing; $28 \%$ commercial; $17 \%$ services and other uses (sports hall, cultural space, social space, artist studio, etc.), and $4 \%$ places of worship.
The remaining $4 \%$ are two parking areas, three offices, and one brownfield.

Since the historical centre of Sint-Jans-Molenbeek along the canal has a fine-grained inner-city morphology, where most building blocks consist of a closed front of houses surrounding production spaces inside the courtyard of the building block, these conversions happen mainly out of sight. The slow, 'drop by drop' rhythm, with an average of 15 to 16 BPs a year (see Figure 1), seems to reinforce the invisibility of the disappearance of production land. De Boeck et al. (in press) argue that the invisibility of production spaces concerns especially small production spaces below $1,000 \mathrm{~m}^{2}$. While the BCR authorities map production space of only $1,000 \mathrm{~m}^{2}$ and more, their research of the construction sector demonstrates that construction enterprises remain spatially invisible for policy because they mostly operate from smaller parcels, between $130 \mathrm{~m}^{2}$ and $520 \mathrm{~m}^{2}$. The conversions in the residential, mixed residential, and

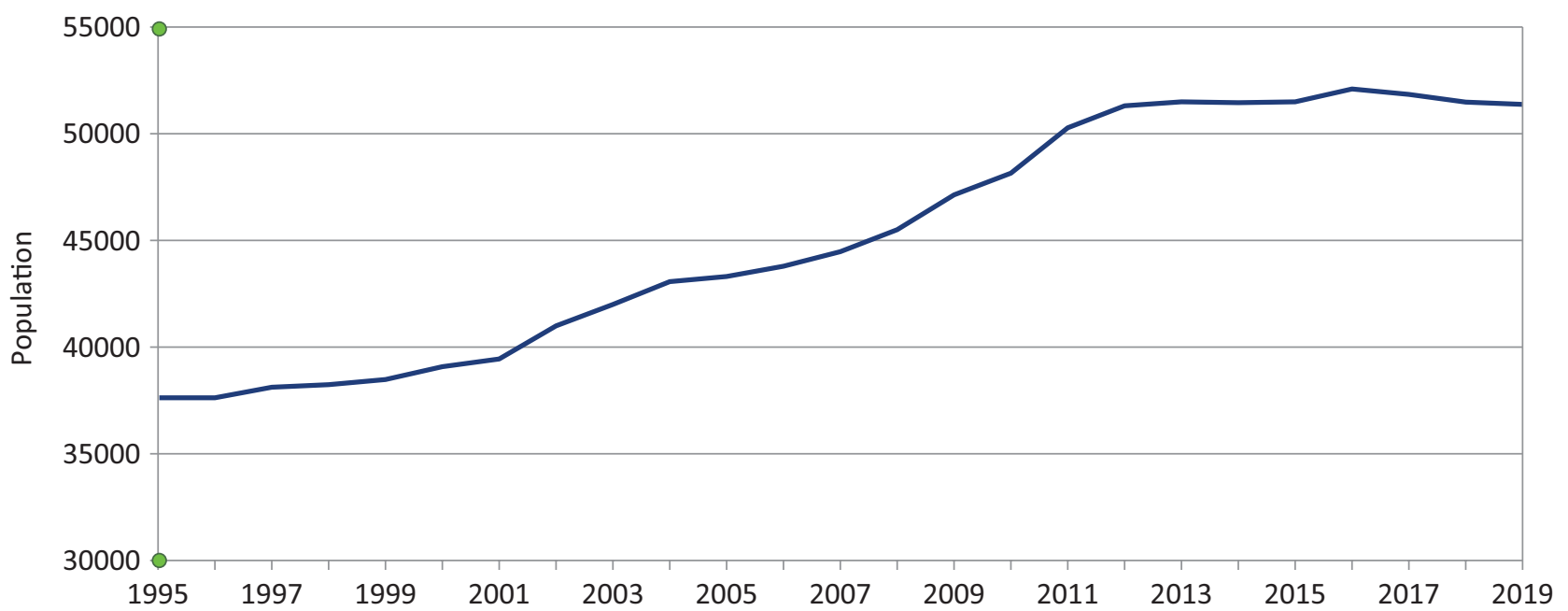

Figure 2. Evolution of population between 1995 and 2019 in Sint-Jans-Molenbeek. Source: Wijkmonitor Brussel (2019), processed by Sarah De Boeck. 
strongly mixed residential areas hence remain out of sight for policymakers.

We conclude that the zoning measures to plan production space in the residential, mixed, and strongly mixed residential areas, namely the categories USPP-1 and USPP-2, do not contain protective measures to safeguard inner-city production space. Through the methodology of measuring production surfaces from $1,000 \mathrm{~m}^{2}$ upwards, the smaller conversions in these zoning areas are mainly invisible to policymakers. Although the building blocks maintained a strong mix in 2001, the year of consolidation of the current BCR land-use plan, these blocks develop step by step into mono-residential areas. We consider this change as industrial gentrification, mainly driven by individual actors in a context of demographic growth and a private real estate market.

\subsubsection{Mono-Industrial Areas}

In the category USPP-3 in Table 1, we find the traditional mono-industrial zone. The BCR has two peripheral areas for urban industry that consist of privately owned plots: one in the north and one in the south, both along the Brussels-Charleroi canal. Occasionally, private actors request permission to turn a part of the site into offices. The disappearance of production space for urban industry in these areas almost exclusively happens through a change of policy instruments, whereby public authorities transform former mono-industrial land into mixed-use land. This change of policy instruments is legitimized in the BCR by the same arguments as those used in London, namely the need to construct housing to host the demographic growth of the region (Ferm \& Jones, 2016, 2017). The Port of Brussels is the public authority that hosts the smallest harbour of Belgium. It manages a large area for port activities and transport in the north of the BCR, adjacent to the area for urban industry, and several smaller inner-city plots along the locks to bridge the different water levels of the canal. Both kinds of mono-industrial zoning seem to provide the best guarantee of preserving production land and related logistic activities, since almost no conversions take place.

In the theoretical section, we saw that although most authors of industrial retention literature agree that mono-industrial zoning is the best strategy to guarantee the affordability of production land and reduce conflicts between production and housing (Borret, 2018; Fitzgerald \& Leigh, 2002), Armstrong and Lund (2005) and Schleicher and Hills (2010) point to the risk of underuse and abandonment caused by a lack of investment incentives, which might make inhabitants protest against derelict buildings in mono-industrial zones. Therefore, they advocate for the conversion of mono-industrial zoning into mixed-use zoning. We examine this hypothesis for the BCR with the vacancy rates of production space. De Voghel et al. (2018), writing for the Brussels planning department 'Perspective,' register a vacancy rate of $12 \%$, but immediately nuance this number. Only $4.2 \%$, or
$173,065 \mathrm{~m}^{2}$, of these $12 \%$ is truly vacant. The rest is on the market for sale or rent, or is part of a building permit, under construction, or under study. While more than half of this $4.2 \%$ of 'real' vacancy $\left(58 \%\right.$, or $\left.100,377 \mathrm{~m}^{2}\right)$ occurs in the areas for urban industry and the areas for port activities and transport $\left(13 \%\right.$, or $\left.23,000 \mathrm{~m}^{2}\right)$, the percentage is too small to support the hypothesis and argue against the preservation of mono-industrial zones. Most of these buildings are indeed underused, in a derelict state, or protected heritage, which might hinder a renovation. Still, however, the Brussels planning department describes this situation as 'tense' and expresses its worries about the lack of a cyclical stock of production spaces (De Voghel et al., 2018, p. 60).

Moreover, there is broad consensus on the preservation and protection of both private and public urban mono-industrial zones. The results of the public inquiry concerning the conversion of the land-use plan from mono-industrial zones to mixed-use development zones reflect this consensus. The resistance and negative appraisal expressed in residents' reactions (Commission Régional de Développement, 2012) contradicts the hypothesis of Armstrong and Lund (2005) and Schleicher and Hills (2010). Nonetheless, there is a debate on opening part of the areas for port activities and transport to recreation after working hours, to connect the cycling lanes and promenades along the canal.

\subsubsection{Mixed-Use Development Areas}

The enterprise areas for urban development of USPP-4 in Table 1 are a relatively new type of zone in the BCR, dating from 2014. This zone has a set of building regulations that imposes a vertical mix with production (and wholesale) on the ground floor and housing (and other functions such as offices or public services) on upper floors. Since the first public and private development projects are under negotiation or construction, it is difficult to evaluate the disappearance of production in the mixed-use development zones and to support this evaluation with data. Therefore, this article leans on academic literature and a review of regulations in the Brussels case to point to three risks concerning the preservation of production space in enterprise areas for urban development.

First, the introduction of housing into these zones negatively influences the affordability of land (Ferm \& Jones, 2017). The introduction of higher value uses, whether these are commercial, industrial, or residential, generates industrial displacement through speculation and rising land prices. Even the diversification of mono-industrial zones with only closely related economic activities cannot avoid an increase in land prices (cf. Hutton, 2009).

Second, next to instigating a dynamic of industrial gentrification, the USPP-4 of vertical mixed-use development might constrain the possibilities for certain kinds of production. Regarding the needs and strategies for keep- 
ing productive activities in cities, the compatibility of activities is a popular strategy used to address the need to reduce conflicts between uses, support the complexity of production processes, and make efficient use of scarce land resources. Academic literature and new urban industrial plans demonstrate how immaterial activities are popular in mixed-use environments. The recent transformation of the BCR land-use plan was accompanied by a change of the definition of urban production and introduced 'immaterial production' to facilitate the implementation of immaterial activities in the enterprise areas for urban development. Moreover, immaterial production activities subscribe to financial reasoning, since Cotter (2012), among others, argues that R\&D and similar forms of light manufacturing can afford higher land rents. It appears that immaterial activities are attractive to urban governments as well as private developers because they are compatible with housing and because of higher rents, but they risk displacing material production activities.

Related to this hypothesis on the pushing out of material production activities for more lucrative uses in vertically mixed schemes, Ferm and Jones (2016) point to the speculative mechanisms and the promise of higher rents of converting production spaces into retail spaces in vertically mixed developments in London. The authors found that developers responsible for the sale and lease of the production spaces on the ground floor claimed not to find the proper production businesses as outlined in the zoning laws. The pressure of developers to relax the zoning laws, in combination with the fear of the negative impact of 'dead facades' of empty spaces on the ground floor, is convincing local governments to give in to the demands of developers and allow retail to replace production. This example illustrates how mixed-use development answers to financial reasoning of value-capturing rather than to the need for maintaining production in the city. The potential consequence of this evidence is not necessarily displacement of material production, but rather a complete absence of production whatsoever in mixed-use neighbourhoods.

Third, the zoning typology of enterprise areas of urban development goes together with rigid building regulations. Borret (2018) questions the combination of the increasing use of conflicts between housing and production on the one hand and the lack of lively ground floors on the other hand. The building regulations permit dense programming of the sites. Some of the issues that need to be addressed include the requirements for logistical access to productive activities; the problems of locating housing structures with smaller floor spans and building depth on top of productive buildings requiring larger floor spans and building depth; the need to provide highquality outdoor spaces for residents or public amenities such as schools or day-care centres; etc. When you install production on the ground floor, the realm of the public, or the interaction between the private and public space, moves to the courtyard of the building block. This might also increase conflicts between uses, because the courtyard becomes a busy and lively place, hosting logistic activities and the loading and unloading of trucks, instead of a quiet backyard.

To conclude, the analysis of the disappearance of production space in the zones of the BCR land-use plan demonstrates that industrial gentrification is an important factor in continuing deindustrialization. In the mixed inner-city areas of USPP-1 and USPP-2, mainly private actors influence this process of displacement. In the EAUDs or mixed peripheral zones, this occurs principally through the introduction of housing in former mono-industrial areas by the public authorities.

\section{Conclusions and Recommendations}

In the analysis of the USPPs, industrial gentrification emerges as the main driver of the decline of productive space in the BCR.

First, the analysis demonstrates that mono-industrial zones in USPP-3 of Table 1 experience little to almost no conversions into uses other than production. The risks attributed to vacancy and dereliction, such as the development of a negative attitude among inhabitants towards productive activities in urban areas, are not supported by the Brussels case. Our analysis confirms that monofunctional areas remain the best strategy to preserve affordable production spaces in cities.

Second, the decline of production space in monofunctional areas is mainly driven by public authorities changing the land-use plan and transforming USPP-3 areas into mixed-use USPP-4 areas. These government-led processes of industrial gentrification contribute to reinforcing real estate dynamics. The analysis shows that the risks of this re-zoning strategy are twofold. First, because of the combination of financial reasons and reasons related to the compatibility of uses, these production spaces might prioritize immaterial production and retail over material production. Second, because of the rigid building prescriptions of vertical mix related to this type of zoning, this typology risks increasing the conflicts between uses of housing and production.

Third, the micro-data about BPs in Sint-JansMolenbeek shows that mainly private actors drive the conversions in residential and mixed residential areas of USPP-1 and USPP-2 of Table 1 . Since many of these conversions of smaller production spaces happen in the courtyard of building blocks, and since the government measures production space only from $1,000 \mathrm{~m}^{2}$ upwards, this process is invisible to policymakers. The micro-data also indicates that the decline of production space is part of industrial gentrification, where especially housing replaces former industrial buildings. The transformation of these mixed-use zones into mono-residential zones takes place due to the absence of protection measures for production.

The question then is whether certain types of zoning measures can safeguard production space in mixed-use 
inner-city areas. Considering industrial gentrification as a significant driver of the decline in production land, we suggest that remedying zoning strategies need to interfere in the real estate dynamics. We recommend three potential zoning strategies to regulate the private market of land in the BCR that need further research: (1) improving the zoning instrument of EAUD; (2) heritage regulation; and (3) micro-zoning.

First, can we use the zoning typology of the EAUD of USPP-4 the other way around and use it to implement a minimum of production spaces in the residential and mixed and strongly mixed residential areas of USPP- 1 and USPP2? Instead of stipulating a minimum of $40 \%$ of housing in the current zoning prescriptions of the EAUD, a minimum percentage of productive space can be preserved in these mixed building blocks to guarantee small-scale inner-city production spaces. As a possible consequence, the introduction of low-value uses into high-value use residential areas might decrease real estate prices. Here we can learn from the current rigid building prescriptions going together with the zoning typology of the EAUD and allow enough flexibility to prevent the negative outcomes expected in the USPP4, where a vertical mix typology is enforced. Both horizontal juxtaposition and vertical stacking of housing and production should fit within zoning regulations for mixed-use areas.

Second, in USPP-1 and USPP-2, additional heritage regulation could help and support a mixed-use zoning strategy. Indeed, in these areas, productive spaces often take the shape of workshops and warehouses dating from the 19th and early 20th century, with distinct heritage values. Current heritage regulations focus on the preservation of the architecture of such buildings but not their original productive use, resulting in residential loft projects or offices (Vandyck \& Degraeve, 2019). Expanding heritage regulations with the protection of productive uses could support the preservation of productive spaces in these USPP-1 and USPP- 2 .

Third, some authors, such as Lane (1995), criticize mono-industrial zones because they are unable to address the need to accommodate complex production processes. However, micro-zoning increases the degree of complexity in the areas surrounding mono-industrial zones as well as in more the fine-grained inner-city areas. Micro-zoning is the small-scale juxtaposition of productive and other uses at the level of the building block. Borret (2018) presents micro-zoning as a strategy to increase urbanity, where streets and sidewalks remain important places of interaction between private and public space. Starting from the uniqueness of the BCR land-use plan, where every building block has its proper zoning typology, further research could clarify whether microzoning can be implemented.

Zoning policy plays a significant role in maintaining urban productive spaces and indirectly impacting real estate dynamics to counter industrial gentrification in a private property market. But zoning remains a rather 'passive' spatial planning instrument. More active support for urban productive spaces comes from public land policies that directly intervene in the real estate market.

A first strategy consists of building and enlarging a production heritage based on the renovation of existing buildings or new construction. Leasing instead of selling this public production property guarantees affordable workspaces in the long term. In the BCR, Citydev is the public real estate developer operating a portfolio of productive assets as well as residential and mixeduse development projects. Citydev has 45 years of experience in constructing and leasing new production assets. They consist of extensive developments of industrial and business parks on brownfields or greenfields in peripheral areas of the region and hosted more than 24,000 jobs in 2016. More recently, Citydev also built a series of smaller production spaces of approximately $100 \mathrm{~m}^{2}$ per unit. Vacancy rates lower than $10 \%$ indicate the success of these assets in various sizes. Here, the public developer could join forces with other public authorities that have more field expertise in local economic development, such as Hub, or could co-govern these spaces through a mix of public and private actors. Most of Citydev's current assets are located in USPP-3 and some in USPP-4. Acquiring and managing assets in USPP-1 and USPP-2 as well, where Citydev is not very present, is a more active public strategy to counter the industrial gentrification of small-scale production spaces in innercity areas.

Second, for mixed-use projects, similar leasehold schemes could be developed. Different regimes would emerge with leaseholds for the production spaces and owner-occupancy or private renting for the residential spaces. A possible alternative is the CLT model that separates home-ownership from ownership of the land (Davis, 2014; Midheme \& Moulaert, 2013). When applied to productive activities and mixed-use projects, the CLT model potentially offers several advantages. First, the model takes the cost of land out of the equation, for residents and businesses alike, adding to that a mechanism to valorise the buildings. This implies more careful decisions about the re-use of buildings and reduces the vacancy risk. Second, as the trust is composed of public authorities, residents, and other users as well as neighbours/neighbourhood associations, any decision on new or future activities involves their concerns and needs. During occupancy, users and residents co-govern and manage the project (Aernouts \& Ryckewaert, 2018). This creates an arena where potential conflicts between uses and nuisances are mitigated and resolved on a more permanent basis, rather than through 'passive' zoning regulations. Citydev is increasingly interested in leasehold mechanisms for residential projects, as illustrated by its recent collaboration with the Brussels CLT. This article presents the CLT strategy, therefore, as a viable way to develop and manage mixed-use projects where the barriers between ownership and leasing are replaced by a strategy of long-term stewardship of affordable land. 


\section{Acknowledgments}

We would like to thank the anonymous reviewers and the editors of Urban Planning, who contributed to the creation of this article. Our thanks also goes to the municipality of Sint-Jans-Molenbeek, and to Raphaël Cielen in particular, for his great help in compiling the data. Many thanks also to Jan Zaman for the never-ending dialogue about urban development in Brussels, and to David Bassens and Heidi Deneweth of the Vrije Universiteit Brussel for their critical reading of the text. This research was made possible by the Interdisciplinary Research Project "Building Brussels. Brussels' city builders and the production of space, 1794-2015" of the Vrije Universiteit Brussel.

\section{Conflict of Interests}

The authors declare no conflict of interests.

\section{References}

Aernouts, N., \& Ryckewaert, M. (2018). Beyond housing: On the role of commoning in the establishment of a Community Land Trust project. International Journal of Housing Policy, 18(4), 503-521.

Armstrong, R., \& Lund, T. (2005). Up from the ruins: Why rezoning New York City's manufacturing areas for housing makes sense. New York, NY: Center for Rethinking Development at the Manhattan Institute. Retrieved from https://docplayer.net/41816887Up-from-the-ruins-why-rezoning-new-york-city-smanufacturing-areas-for-housing-makes-sense.html

Borret, K. (2018). Brussels productive city. Brussels: Bouwmeester Maitre Architecte and Perspective. Retrieved from https://bma.brussels/wp-content/ uploads/2018/12/BRUSSELS-PRODUCTIVE-CITY.pdf

Brearly, M. (2016, January 2). A good city has industry [Video file]. Retrieved from https://www.youtube. com/watch?v=XzM3AERvM70

Brussels Capital Region. (2017). Demografisch gewestelijk bestemmingsplan [Regional land-use plan]. Brussels: Perspective.

Brussels Instituut voor Statistiek en Analyse. (2020). Gewestelijke bevolkingsprojecties: Jaarlijkse bevolkingsevolutie 2020-2070 (in aantal personen) [Regional population projections: Yearly evolution of population 2020-2070 (in number of individuals)]. Brussels Instituut voor Statistiek en Analyse. Retrieved from https://bisa.brussels/themas/ bevolking/bevolkingsprojecties

Camerin, F. (2019). From 'Ribera plan' to 'Diagonal mar,' passing through 1992 'Villa Olimpica.' How urban renewal took place as urban regeneration in Poblenou district (Barcelona). Land Use Policy, 89, 104226.

Catungal, J. P., Leslie, D., \& Hii, Y. (2009). Geographies of displacement in the creative city: The case of Liberty Village, Toronto. Urban Studies, 46(5/6), 1095-1114.
Chapple, K., St.-Louis, E., Ritter, S., Ross, Á., Mattiuzzi, E., Crispell, M., ... Cochran, A. (2017). Deconversion of industrially zoned land (Report prepared for the Association of Bay Area Governments/Metropolitan Transportation Commission). Sacramento, CA: Government of California. Retrieved from https:// dot.ca.gov/-/media/dot-media/programs/researchinnovation-system-information/documents/finalreports/ca17-2792-finalreport-a11y.pdf

Charnock, G., Purcell, T. F., \& Ribera-Fumaz, R. (2014). City of rents: The limits to the Barcelona model of urban competitiveness. International Journal of Urban and Regional Research, 38(1), 198-217.

Cities of Making. (2018). Homepage. Cities of Making. Retrieved from www.citiesofmaking.com

Commission Régional de Développement. (2012, October 29). Pras démographique: Avis de la Commission Régionale de Développement [Demographic land-use plan: Advice of the Regional Development Commission of the Brussels capital region]. Brussels: Commission Régional de Développement. Retrieved from http://www.crd-goc.be/wp/wp-content/uploads/ 12215-1894AD1.pdf

Cotter, D. (2012). Putting Atlanta back to work: Integrating light industry into mixed-use urban development. Atlanta, GA: Georgia Tech Enterprise Innovation Institute. Retrieved from http://stip.gatech.edu/ wp-content/uploads/2012/10/STIP-Dan-Cotter.pdf

Curran, W. (2007). 'From the frying pan to the oven': Gentrification and the experience of industrial displacement in Williamsburg, Brooklyn. Urban Studies, 44(8), 1427-1440.

Curran, W. (2010). In defense of old industrial spaces: Manufacturing, creativity and innovation in Williamsburg, Brooklyn. International Journal of Urban and Regional Research, 34(4), 871-885.

Davis, J. E. (2014). Origins and evolution of the Community Land Trust in the United States. In J.E. Davis (Ed.), The community land trust reader (pp. 3-47). Cambridge, MA: Lincoln Institute of Land Policy.

De Boeck, S. (2020). Making space for the foundational economy: Urban economic policy and planning perspectives from Brussels (Unpublished Doctoral dissertation). Vrije Universiteit Brussel, Brussels, Belgium.

De Boeck, S., Bassens, D., \& Ryckewaert, M. (2019). Making space for a more foundational economy: The case of the construction sector in Brussels. Geoforum, 105, 67-77.

De Boeck, S., Degraeve, M., \& Vandyck, F. (in press). Maintaining small-scale production space in the city: The case of Brussels construction companies (1965-2016). Brussels Studies.

De Voghel, C., Strale, M., Boswell, R., \& Coekelberghs, S. (2018). Observatory of productive activities: Logistics real estate and Survey 2017. Brussels: Perspective. Retrieved from https://perspective.brussels/sites/ default/files/documents/perspective-brochure_ observatoire-04-2018_web.pdf 
Ferm, J., \& Jones, E. (2016). Mixed-use 'regeneration' of employment land in the post-industrial city: Challenges and realities in London. European Planning Studies, 24(10), 1913-1936.

Ferm, J., \& Jones, E. (2017). Beyond the post-industrial city: Value and planning for industry in London. Urban Studies, 54(14), 3380-3398.

Fitzgerald, J., \& Leigh, N. G. (2002). Economic revitalization: Cases and strategies for cities and suburbs. Thousand Oaks, CA: Sage.

Hill, A. V. (Ed.). (2020). Foundries of the future: A guide for 21st century cities of making. Brussels: Cities of Making.

Hoppenbrouwer, E., \& Louw, E. (2005). Mixed-use development: Theory and practice in Amsterdam's Eastern docklands. European Planning Studies, 13(7), 967-983.

Hutton, T. A. (2009). Trajectories of the new economy: Regeneration and dislocation in the inner city. Urban Studies, 46(5/6), 987-1001.

Indegaard, M. (2009). What to make of New York's new economy? The politics of the creative field. Urban Studies, 46(5/6), 1063-1093.

Kampelmann, S. (2017). Circular economy in a territorial context: The case of biowaste management in Brussels. In I. Cassiers, K. Maréchal, \& D. Méda (Eds.), Postgrowth economics and society: Exploring the paths of a social and ecological transition (pp. 73-89). London: Routledge.

Lane, R. (1995). The machine next door. Places, 10(1), 10-23.

Leigh, N. G., \& Hoelzel, N. Z. (2012). Smart growth's blind side: Sustainable cities need productive urban industrial land. Journal of the American Planning Association, 78(1), 87-103.

Lester, T. W., Kaza, N., \& Kirk, S. (2013). Making room for manufacturing: Understanding industrial land conversion in cities. Journal of the American Planning Association, 79(4), 295-313.

Midheme, E., \& Moulaert, F. (2013). Pushing back the frontiers of property: Community land trusts and lowincome housing in urban Kenya. Land Use Policy, 25, 75-84.

Moritz, B., De Clerck, P., \& Vanhaelen, Y. (2013). Re: Work: Making place for industry, wholesale and logistics in Brussels, reports on research by design. Brussels: Université Libre de Bruxelles and Erasmushogeschool Brussel.

Nawratek, K. (2017). Urban re-industrialization. Earth, Milky Way: Punctum Books.

Rowthorn, R., \& Ramaswamy, R. (1999). Growth, trade, and deindustrialization. IMF Staff Papers, 46(1), 18-41. Retrieved from https://www.imf.org/ external/Pubs/FT/staffp/1999/03-99/pdf/ rowthorn.pdf

Ryckewaert, M. (2011). Building the economic backbone of the Belgian welfare state: Infrastructure, planning and architecture 1945-1973. Rotterdam: 010 Publishers.

Saeger, S. S. (1997). Globalization and deindustrialization: Myth and reality in the OECD. Review of World Economics, 133(4), 579-608.

Savini, F., \& Aalbers, M. B. (2016). The de-contextualization of land use planning through financialisation: Urban redevelopment in Milan. European Urban and Regional Studies, 23(4), 878-894.

Schleicher, D., \& Hills, R. M. (2010). The steep costs of using noncumulative zoning to preserve land for urban manufacturing. University of Chicago Law Review, 77, 249-273.

Smith, N. (1987). Gentrification and the rent gap. Annals of the Association of American Geographers, 77(3), 462-465.

Stadt Wien. (2015). Fachkonzept Produktive Stadt: Werkstattberichte der Stadtentwicklung Wien (No. 171) [Concept of the productive city: Working report of city development of Vienna, No. 171]. Vienna: Stadt Wien. Retrieved from https://www.wien.gv.at/ stadtentwicklung/studien/b008500.html

Statbel. (2018). Bodembezetting op basis van het kadasterregister per gemeente, gedetailleerde kadastrale aard en per jaar sinds 1982 [Land-use as recorded in the land registry at the scale of the municipality, detailed function per year since 1982]. Statbel. Retrieved from https://bestat.statbel.fgov.be/ bestat/crosstable.xhtml?view=0dade6ed-61fd4316-84d2-1a8f4af2ef40

Tregenna, F. (2011). Manufacturing productivity, deindustrialization, and reindustrialization (Working Paper No. 2011/57). Helsinki: United Nations University, World Institute for Development Economics Research. Retrieved from http://citeseerx.ist. psu.edu/viewdoc/download?doi=10.1.1.644.360\& rep $=$ rep $1 \&$ type $=p d f$

Vandermotten, C. (2014). Bruxelles, une lecture de la ville: De l'Europe des marchands à la capitale de l'Europe. [Brussels, reading the city: From Europe of the merchants to the capital of Europe]. Brussels: Editions de I'Université de Bruxelles.

Vandyck, F., \& Degraeve, M. (2019). 'Baukultur' in Brussels: Small-scale industrial heritage from the building trade as vehicle for the productive city. Bulletin KNOB, 118(4), 20-35.

Wijkmonitor Brussel. (2019). Evolution of population between 1995 and 2019 in Sint-Jans-Molenbeek. Wijkmonitoring Brussel. Retrieved from https:// wijkmonitoring.brussels/tables

Wolf-Powers, L. (2005). Up-zoning New York City's mixeduse neighborhoods: Property-led economic development and the anatomy of a planning dilemma. Journal of Planning Education and Research, 24(4), 379-393. 


\section{About the Authors}
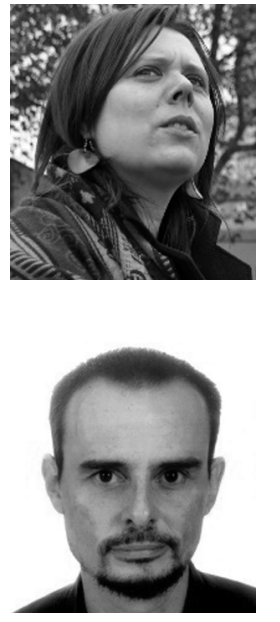

Sarah De Boeck is Doctor in Interdisciplinary Studies at the Vrije Universiteit Brussel and Vice-President of the Regional Development Commission of the Brussels Capital Region. Her research focusses on how to shape the coexistence between economic activity and liveability in metropolitan areas. She develops a foundational economy approach to urban economic development, seeking to recalibrate urban economic policy and planning around those activities rooted in place, sheltered from interurban competition, and essential to the well-being of citizens.

Michael Ryckewaert is Associate Professor of Urbanism and Program Director of the MSc in Urbanism and Spatial Planning at the Vrije Universiteit Brussel. He is also Associate Director of the Cosmopolis Centre for Urban Research. His research focuses on housing, spatial policy, urbanism history and theory, and the role of economic activities in the urbanization in Belgium. 